\title{
The Complex Relationship between Metals and Carbonic Anhydrase: New Insights and Perspectives
}

\author{
Maria Giulia Lionetto *, Roberto Caricato, Maria Elena Giordano and Trifone Schettino \\ Received: 2 December 2015; Accepted: 11 January 2016; Published: 19 January 2016 \\ Academic Editor: Reinhard Dallinger \\ Department of Biological and Environmental Science and Technologies (DiSTeBA), University of Salento, \\ Via Prov.le Lecce-Monteroni, 73100 Lecce, Italy; roberto.caricato@unisalento.it (R.C.); \\ elena.giordano@unisalento.it (M.E.G.); trifone.schettino@unisalento.it (T.S.) \\ * Correspondence: giulia.lionetto@unisalento.it; Tel.: +39-0832-298694; Fax: +39-0832-298626
}

\begin{abstract}
Carbonic anhydrase is a ubiquitous metalloenzyme, which catalyzes the reversible hydration of $\mathrm{CO}_{2}$ to $\mathrm{HCO}_{3}{ }^{-}$and $\mathrm{H}^{+}$. Metals play a key role in the bioactivity of this metalloenzyme, although their relationships with CA have not been completely clarified to date. The aim of this review is to explore the complexity and multi-aspect nature of these relationships, since metals can be cofactors of CA, but also inhibitors of CA activity and modulators of CA expression. Moreover, this work analyzes new insights and perspectives that allow translating new advances in basic science on the interaction between CA and metals to applications in several fields of research, ranging from biotechnology to environmental sciences.
\end{abstract}

Keywords: carbonic anhydrase; metals; inhibition; expression; biomarker; bioassay

\section{Introduction}

Carbonic anhydrase (CA) is a widely-distributed metalloenzyme, which catalyzes the reversible hydration of $\mathrm{CO}_{2}$ to $\mathrm{HCO}_{3}{ }^{-}$and $\mathrm{H}^{+}$. This biochemical reaction plays a key physiological role in diverse biological systems. Six distinct and unrelated CA families $(\alpha-, \beta-, \gamma-C A, \delta, \zeta$ and $\eta$-CAs) have been identified in animals, plants, algae and bacteria [1,2]. They all catalyze the same reaction of $\mathrm{CO}_{2}$ hydration, but each family shows proper specific characteristics in primary amino acid sequence and 3D tertiary structure.

In animals, CA isoforms play a fundamental role in a number of physiological processes involving carbon dioxide and bicarbonate, such as transport of $\mathrm{CO}_{2}$ and $\mathrm{HCO}_{3}{ }^{-}$between body tissues and respiratory surfaces, $\mathrm{pH}$ homeostasis, electrolyte transport in various epithelia, biosynthetic reactions (gluconeogenesis, lipogenesis and ureagenesis), bone resorption and calcification. In algae, plants and some bacteria, CA isoforms are fundamental for photosynthesis $[3,4]$.

The $\alpha$-carbonic anhydrases are monomeric or dimeric and are found in animals, some fungi, bacteria, algae and green plants [5]. In mammals, at least 16 different $\alpha \mathrm{CA}$ isoforms were isolated. Mammalian CA isoforms CAI, II, III, IV, VA, VB, VI, VII, IX, XII, XIII, XIV and CA XV (not expressed in humans) have catalytic activity, while the remaining three CAs (CARP VIII, CARP X and CARP XI) have lost the catalytic activity and are known as CA-related proteins [6].

The $\beta$-carbonic anhydrases are dimers, tetramers or octamers and are expressed mainly in fungi, bacteria, archaea, algae and chloroplasts of monocotyledons and dicotyledons [7] and some prokaryotes [8].

The $\gamma$-anhydrase class is a homotrimer that has been described in bacteria, Archaea and plants [9]. It also includes a number of non-catalytically-active homologs present in diverse species. $\delta$ - and $\zeta$-CAs are present in several classes of marine phytoplankton. The $\delta$ class has been described in diatoms, and 
its prototype is the CA TWCA1 from the marine diatom Thalassiosira weissflogii [10,11]. The $\zeta$-CAs are probably monomers and have three slightly different active sites on the same protein molecule [12].

The $\eta$-CA was recently found in a number of species of the Plasmodium genus. These are a group of enzymes previously ascribed to the $\alpha$ family, but recently demonstrated to have a number of unique features, including their metal ion coordination pattern [2].

This review focuses on an interesting aspect of the research on CA, the relationships between carbonic anhydrase and metals, which play a fundamental role in the bioactivity of this metalloenzyme. The review points out the complexity and multi-aspect nature of these relationships, since metals can be cofactors of CA, but also inhibitors of CA activity and modulators of CA expression. New insights and perspectives are discussed encompassing several fields of research from biotechnological applications to environmental sciences.

\section{Metals and CA Catalytic Site}

All CA isoenzymes catalyze the reversible hydration of $\mathrm{CO}_{2}$ to $\mathrm{HCO}_{3}$ and $\mathrm{H}^{+}$through a metal-hydroxide $\left[\mathrm{Lig}^{3} \mathrm{M}^{2+}(\mathrm{OH})^{-}\right.$] mechanism [13-15] (Figure 1). The central catalytic step involves the reaction between $\mathrm{CO}_{2}$ and the $\mathrm{OH}^{-}$bound to the zinc ion, yielding a coordinated $\mathrm{HCO}_{3}{ }^{-}$ion, which is subsequently displaced from the metal by $\mathrm{H}_{2} \mathrm{O}$. In the $\alpha-, \gamma$ - and $\delta$-CA classes, $\mathrm{Lig}^{3}$ is represented by three key amino acid residues, which are three histidines in $\alpha-C A, \gamma-C A$ and $\delta$-CA, one histidine and two cysteines in $\beta$-CA and $\zeta$-CA and two His and one Gly residues in $\eta$-CA [16]. A fourth histidine, that is His 64 in human CAII (the most investigated CA isoform), not directly part of the active site, contributes to the catalytic process representing the so-called "proton shuttle". This allows the $\mathrm{H}^{+}$ transfer from the metal-bound water molecule to buffer molecules located outside the active site and ensures the reaction of the metal-bound $\mathrm{OH}^{-}$with $\mathrm{CO}_{2}$ to produce $\mathrm{HCO}_{3}{ }^{-}$.

The metal (M) in the carbonic anhydrase metal-hydroxide $\left[\mathrm{Lig}^{3} \mathrm{M}^{2+}(\mathrm{OH})^{-}\right]$mechanism is $\mathrm{Zn}^{2+}$ for all classes, but other transition metals have been demonstrated to bind to the catalytic site as physiologically-relevant metal cofactors or displacers of the native cofactor, producing in this case new CA metallovariants (Table 1).

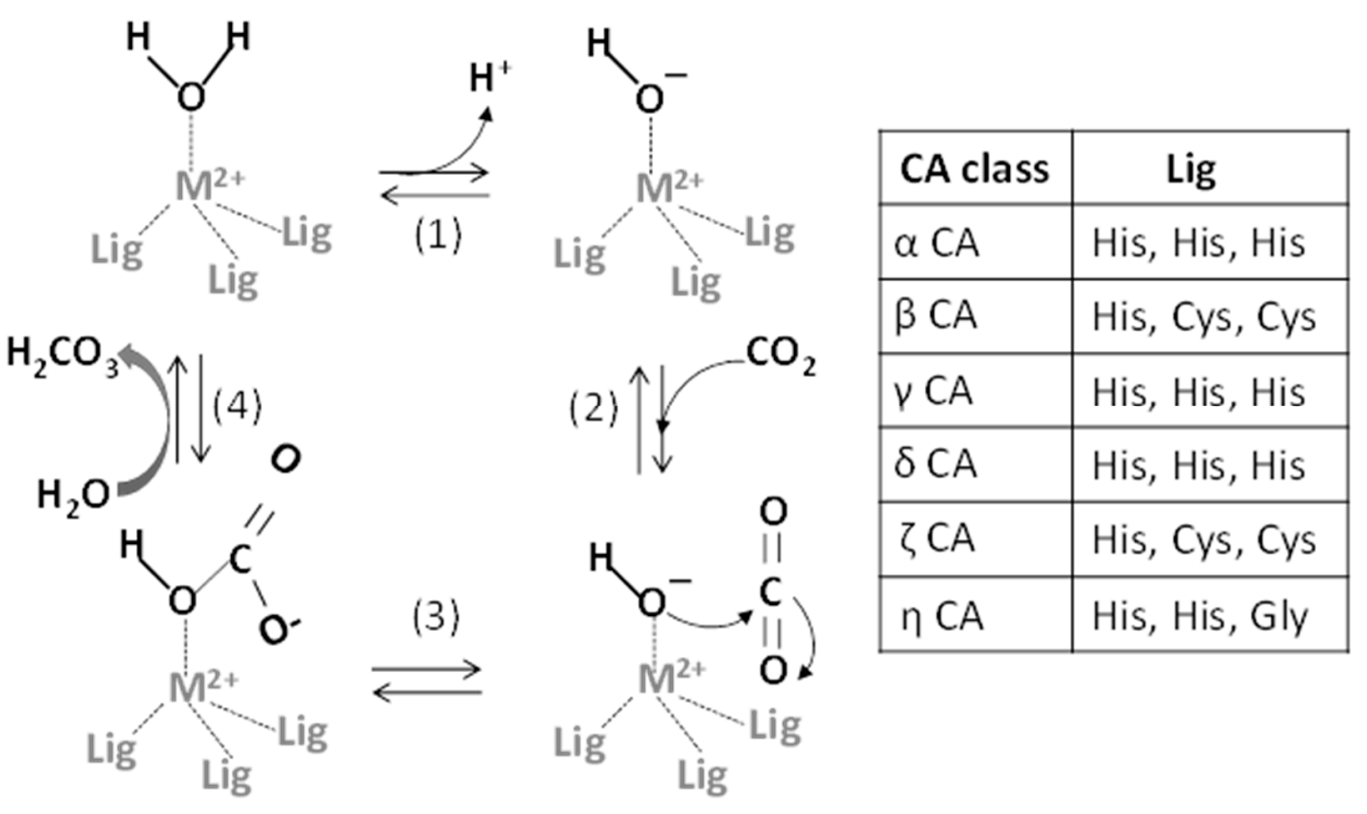

Figure 1. The reversible hydration of carbon dioxide to bicarbonate catalyzed by CAs by means of a metal (M)-hydroxide mechanism. Modified from Berg [17]. (1) The release of a proton from the zinc-bound water generates the zinc-bound $\mathrm{OH}^{-}$; (2) $\mathrm{A} \mathrm{CO}_{2}$ molecule binds to the active site and is positioned for optimal interaction with the zinc-bound $\mathrm{OH}^{-}$; (3) The hydroxide ion attacks the carbonyl of $\mathrm{CO}_{2}$, producing $\mathrm{HCO}_{3}{ }^{-}$; (4) The release of $\mathrm{HCO}_{3}{ }^{-}$regenerates the enzyme. 
Table 1. Metals as physiologically-relevant cofactors of CA.

\begin{tabular}{ccc}
\hline CA Families & Metals as Physiologically-Relevant CA Cofactors & Ref. \\
\hline$\alpha-C A$ & $\mathrm{Zn}^{2+}$ & {$[21]$} \\
$\beta-C A$ & $\mathrm{Zn}^{2+}$ & {$[7]$} \\
$\gamma-\mathrm{CA}$ & $\mathrm{Fe}^{2+} ; \mathrm{Zn}^{2+}$ & {$[9,22]$} \\
$\delta$-CA & $\mathrm{Zn}^{2+}$ & {$[10]$} \\
$\zeta-\mathrm{CA}$ & $\mathrm{Cd}^{2+} ; \mathrm{Zn}^{2+}$ & {$[12]$} \\
$\eta-\mathrm{CA}$ & $\mathrm{Zn}^{2+}$ & {$[2]$} \\
\hline
\end{tabular}

Apart from zinc, other metals have been found to be physiologically-relevant cofactors of some CAs.

\subsection{Metals as Physiologically-Relevant Cofactors of CA}

$\mathrm{Zn}^{2+}$ is one of the most widely-used metallic elements as enzyme cofactor in nature, and its presence in all of the CA families is a successful confirmation of its peculiar properties. The reason for its success lies in the filled $d$ orbital (d10). Unlike other first-row transition elements (e.g., $\mathrm{Sc}^{2+}$, $\mathrm{Ti}^{2+}, \mathrm{V}^{2+}, \mathrm{Cr}^{2+}, \mathrm{Mn}^{2+}, \mathrm{Fe}^{2+}, \mathrm{Co}^{2+}, \mathrm{Ni}^{2+}$ and $\left.\mathrm{Cu}^{2+}\right), \mathrm{Zn}^{2+}$ is not involved in redox reactions, but rather, it acts as a Lewis acid accepting a pair of electrons [18]. This makes zinc a good metal cofactor for biochemical reactions requiring a redox-stable ion to function as a Lewis acid-type catalyst [19], such as proteolysis and carbon dioxide hydration. Zinc complexes have low thermodynamic stabilities, as well as variable geometries, which in turn account for low activation barriers. This makes zinc a versatile and suitable as an active site metal [20]. Zinc is in the +2 state, and it is positioned in a cleft in the center of the CA molecule (Figure 2). It is coordinated by the three key amino acid residues (see above). The fourth coordination site is occupied by a water molecule. The role of $\mathrm{Zn}^{2+}$ in the CA catalytic mechanism is to promote the deprotonation of $\mathrm{H}_{2} \mathrm{O}$ with the production of the nucleophilic $\mathrm{OH}^{-}$, which in turn can attack the carbonyl group of $\mathrm{CO}_{2}$ to convert it into $\mathrm{HCO}_{3}{ }^{-}$. A water molecule subsequently displaces the bicarbonate at the metal (Figure 1).

$\mathrm{Fe}^{2+}$ has been demonstrated to be a physiological metal cofactor of $\gamma$-CAs [22,23]. The $\gamma$-CA class is among the most ancient, with homologs widespread in Archaea and Bacteria [24]. CAM, the prototypic $\gamma$-class CA from the anaerobic Archaea species Methanosarcina thermophila, has been demonstrated to contain zinc in the active site when overproduced in Escherichia coli and purified in aerobic experimental conditions [22]. On the other hand, when the enzyme is purified anaerobically, it has been demonstrated to contain $\mathrm{Fe}^{2+}$ in the active site (Fe-CAM) and to have a three-fold increased activity. These contrasting results are explained by the fact that in aerobic conditions, $\mathrm{Fe}^{3+}$ is oxidized and is rapidly substituted by $\mathrm{Zn}^{2+}$ present in the reaction buffers not treated with chelating agents. The stability of complexed $\mathrm{Zn}^{2+}$ is much greater than that for $\mathrm{Fe}^{2+}$ ligated with the nitrogen atoms of histidine residues coordinating the active-site metal in CAM. Thus, aerobic purification results in the loss of $\mathrm{Fe}^{3+}$ and substitution with $\mathrm{Zn}^{2+}$. These findings clearly suggest $\mathrm{Fe}^{2+}$ as the physiologically-relevant metal [22-24] in the active site of the CAM enzyme. Considering that $\mathrm{Fe}^{2+}$ is available in oxygen-free environments, the finding of iron as a physiological metal cofactor in CAM from an anaerobic species suggests the possibility that iron could act as a metal cofactor in $\gamma$-class CA enzymes and possibly in other classes in anaerobic organisms [23]. Moreover, evidence for the role of $\mathrm{Fe}^{2+}$ in $\mathrm{CA}$ catalytic activity has been found also in the $\alpha$-class. In fact, in duck erythrocytes, the addition of $\mathrm{Fe}^{2+}$ in the reaction medium increases $\mathrm{CA}$ activity [25].

$\mathrm{Cd}^{2+}$ has been demonstrated to be naturally used as a catalytic metal in the cadmium-carbonic anhydrase (CDCA1), a $\zeta-C A$ isolated from the marine diatom Thalassiosira weissflogii [26-28]. Its homolog gene has been found in a number of diatom species, as well as natural assemblages [12]. CDCA1 provides the first evidence of the biological role of cadmium, which is usually considered a toxic element associated with environmental pollution [29]. CDCA1 is considered a "cambialistic" enzyme because it can use either $\mathrm{Zn}$ or $\mathrm{Cd}$ for the catalytic reaction [12]. The ability to use $\mathrm{Cd}$ in CDCA allows the diatom $T$. weissflogii to support the needs of fast growth also in $\mathrm{Zn}^{2+}$ limiting conditions, and this has ecologically relevant implications. In fact, in the oceans, which are known to be poor 
in metals, this ability might have given a competitive advantage to diatoms with respect to other species, contributing to the radiation of diatoms during the Cenozoic Era and to the parallel decrease in atmospheric $\mathrm{CO}_{2}$ [12]. In the ocean, $\mathrm{Cd}$ shows a nutrient-like concentration profile, with a low concentration at the surface, because of phytoplankton uptake, and an increased concentration at depth due to remineralization of sinking organic matter. This $\mathrm{Cd}$ profile is thought to be explained by the use of this metal by CDCA.

$\mathrm{Co}^{2+}$ has been demonstrated to in vivo substitute $\mathrm{Zn}^{2+}$ in the other genetically-distinct $\mathrm{CA}$ form (TWCA1) ( $\delta$-CA) isolated from the diatom T. weissflogii [30]. Although the affinity of TWCA1 for $\mathrm{Co}^{2+}$ is lower than for $\mathrm{Zn}^{2+}$ and the Co-substituted enzyme is less active than the $\mathrm{Zn}$-form [30], it has been suggested that the $\mathrm{Co}^{2+}$ substitution can alleviate the $\mathrm{Zn}^{2+}$ limitation in diatoms in open oceans, as also suggested for $\mathrm{Cd}^{2+}[26,30]$.

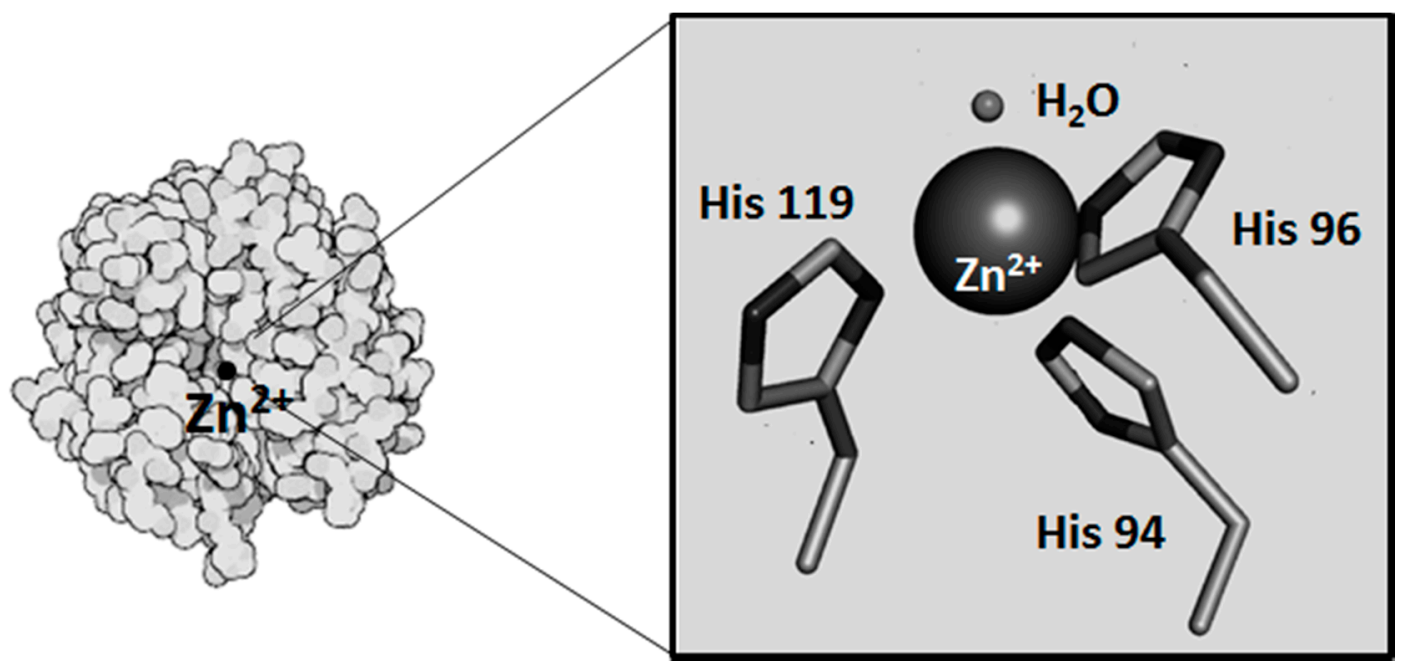

Figure 2. Human CAII: in detail, the metal binding site with the zinc ion as a sphere, the direct ligand histidines, H94, H96, H119, and the water molecule. Modified from Mahon et al [31] and from Dutta and Goodsell [32].

\subsection{Metals as Displacers of the Native Metal Cofactor}

In addition to the role of some metals as CA physiologically-relevant metal cofactors, many divalent metal ions, such as $\mathrm{Co}^{2+}, \mathrm{Ni}^{2+}, \mathrm{Mn}^{2+}, \mathrm{Cu}^{2+}, \mathrm{Cd}^{2+}$ and $\mathrm{Hg}^{2+}$, have been demonstrated to easily bind to the three-histidine moiety within the CA active site in in vitro experimental conditions [33-35]. Most of this information comes from transmetallation experiments on the $\alpha$-CAII. The $\mathrm{CO}_{2}$ hydration catalytic activity of metal-substituted human CAIIs, relative to wild-type CAII activity, is about $7 \%$ for the $\mathrm{Mn}^{2+}$-substituted CA, about $2 \%$ for the $\mathrm{Cd}^{2+}$-substituted and about $0 \%$ for the $\mathrm{Cu}^{2+}$-substituted and $\mathrm{Hg}^{2+}$-substituted ones, respectively [36,37]. Only $\mathrm{Co}^{2+}$ is able to produce a catalytically-functioning enzyme with a wild-type catalytic efficiency $\left(K_{\text {cat }} / K_{\mathrm{m}}=8.7 \times 10^{7} \mathrm{M}^{-1} \cdot \mathrm{s}^{-1}\right.$ for $\mathrm{Zn}^{2+}$ vs. $8.8 \times 10^{7} \mathrm{M}^{-1} \cdot \mathrm{s}^{-1}$ for $\mathrm{Co}^{2+}$ ) [34] because only cobalt besides zinc has a tetrahedral coordination at a $\mathrm{pH}$ around eight. In particular, Co-CA represents an ideal metallovariant for studying the CA catalytic site. In contrast to $\mathrm{Zn}^{2+}$, lacking a spectroscopic signature, the paramagnetic $\mathrm{Co}^{2+}$ is accessible to spectroscopic analysis, providing information about the environment of the metal ions in the CA active site [38].

\subsection{Metal Binding to Other Sites in the CA Protein}

In addition to the ability of some metals to bind the three key amino acid residues of the CA active site, metals are also able to bind CA protein in other sites elsewhere in the molecule thanks to their affinity for thiol and histidyl groups. Mercuric ions have been demonstrated by X-ray 
crystallography [39] to bind to the His-64 ring (the so-called proton shuttle) and also to Cys-206 of CAII [40]. Copper ion is known to bind to the imidazole of His-64 in CAII, preventing its function in the $\mathrm{H}^{+}$transfer from the zinc-bound $\mathrm{H}_{2} \mathrm{O}$ to buffer molecules outside the active site [41]. In addition, $\mathrm{Cu}^{2+}$ is also able to bind CA in another binding site [42] nearby the N-terminus of the proteins, presumably in a four-coordinate tetragonal $\mathrm{Cu}^{2+}$ site with two histidine ligands and an $\mathrm{N}$-terminal amine [43]. Because of the presence of this high affinity site, CA seems to be a member of a growing number of proteins and peptides that have been found to have an $\mathrm{N}$-terminal $\mathrm{Cu}^{2+}$-binding site, including serum albumin and amyloid $\beta$-peptide complexes [43]. It is unknown why CA has this $\mathrm{N}$-terminal $\mathrm{Cu}^{2+}$ site that does not show any catalytic activity. It is possible that this site could function as a sequestering site of adventitious $\mathrm{Cu}^{2+}$. In this respect, an intriguing hypothesis suggests that this $\mathrm{N}$-terminal site can be effective in defending the native zinc(II)-(His)3 active site of CA, as well as other metalloproteins, from $\mathrm{Cu}^{2+}$ displacement, and in turn, inactivation [43].

\section{Metals and CA Activity Inhibition}

The ability of some transition metals either to displace $\mathrm{Zn}^{2+}$ in the active site or to bind histidine and cysteine residues in sites other than the active site accounts for the inhibitory effect of some metals on CA activity, reported by several authors in a number of tissues in a variety of animal species. Table 2 summarizes the results obtained in in vitro studies.

In the teleost fish Ictalurus punctatus, $\mathrm{Cd}^{2+}, \mathrm{Cu}^{2+}, \mathrm{Ag}^{+}$and $\mathrm{Zn}^{2+}$ were demonstrated to inhibit erythrocyte CA activity [44]. In the euryhaline teleost Anguilla anguilla, a significant in vitro tissue-specific inhibition of branchial and intestinal CA activity by $\mathrm{Cd}^{2+}$ was found $[45,46]$. In particular, in the intestine, a cytosolic and a membrane-bound CA were detected, with the cytosolic isoform more sensitive to the metal than the membrane-bound one. In the European seabass (Dicentrarchus labrax), $\mathrm{Al}^{+3}, \mathrm{Cu}^{+2}, \mathrm{~Pb}^{+2}, \mathrm{Co}^{+3}, \mathrm{Ag}^{+1}, \mathrm{Zn}^{+2}$ and $\mathrm{Hg}^{+2}$ were found to be competitive inhibitors of liver $\mathrm{CA}$ activity [47]. In the liver of sea bream (Sparus aurata) $\mathrm{Ag}^{+}, \mathrm{Ni}^{2+}, \mathrm{Cd}^{2+}$ and $\mathrm{Cu}^{2+}$ were shown to be noncompetitive inhibitors of CA activity [48].

In rainbow trout (Oncorhynchus mykiss), $\mathrm{Co}^{2+}, \mathrm{Cu}^{2+}, \mathrm{Zn}^{2+}, \mathrm{Ag}^{+}$and $\mathrm{Cd}^{2+}$ inhibited brain CA activity. $\mathrm{Ag}^{+}$and $\mathrm{Cd}^{2+}$ were competitive inhibitors, $\mathrm{Cu}^{2+}$ was noncompetitive inhibitor, while $\mathrm{Zn}^{2+}$ was uncompetitive inhibitor [49].

In the estuarine crab Chasmagnathus granulate, $\mathrm{Cd}^{2+}, \mathrm{Cu}^{2+}$ and $\mathrm{Zn}^{2+}$ inhibited branchial CA activity both in vitro and in vivo [50]. In other euryhaline crabs, Callinectes sapidus and Carcinus maenas, a significant in vitro inhibition of gill CA by $\mathrm{Ag}^{+}, \mathrm{Cd}^{2+}, \mathrm{Cu}^{2+}$ and $\mathrm{Zn}^{2+}$ was demonstrated, with strong differences between the gill CA of the two species, Callinectes sapidus CA being more sensitive than Carcinus maenas CA [51]. In humans, the cytosolic HCAI and II were in vitro inhibited by $\mathrm{Pb}^{2+}, \mathrm{Co}^{2+}$ and $\mathrm{Hg}^{2+} . \mathrm{Pb}^{2+}$ was noncompetitive inhibitor for HCAI and competitive for HCAII, $\mathrm{Co}^{2+}$ was competitive for HCAI and noncompetitive for HCAII, and $\mathrm{Hg}^{2+}$ was uncompetitive for both isoforms [52].

In the sturgeon Acipenser gueldenstaedti, $\mathrm{Ag}^{+}, \mathrm{Zn}^{2+}, \mathrm{Cu}^{2+}$ and $\mathrm{Co}^{2+}$ were weak inhibitors of the erythrocyte CA activity [53]. In sheep kidney, $\mathrm{Pb}^{2+}, \mathrm{Co}^{2+}, \mathrm{Hg}^{2+}, \mathrm{Cd}^{2+}, \mathrm{Zn}^{2+}, \mathrm{Se}^{2+}, \mathrm{Cu}^{2+}$ and $\mathrm{Al}^{3+}$ competitively inhibited CA activity in the low molar/millimolar range [54]. In the Turkish native chicken, $\mathrm{Al}^{3+}, \mathrm{Hg}^{2+}, \mathrm{Cu}^{2+}, \mathrm{Pb}^{2+}$ and $\mathrm{Cd}^{2+}$ were competitive inhibitors of erythrocyte $\mathrm{CA}$ activity. $\mathrm{Pb}^{2+}$ exhibited the strongest inhibitory action; $\mathrm{Cd}^{2+}$ and $\mathrm{Hg}^{2+}$ were moderate inhibitors, while $\mathrm{Al}^{3+}$ and $\mathrm{Cu}^{2+}$ were weaker inhibitors [55].

$\mathrm{Ki}$ or $\mathrm{IC}_{50}$ values for in vitro metal inhibition of $\mathrm{CA}$ activity range from micromolar to millimolar depending on species, tissue and isoform. Although in some cases the $\mathrm{Ki}$ or $\mathrm{IC}_{50}$ values are in the submillimolar or millimolar range, suggesting a weak inhibition, they may be significant for infield inhibition due to the bioaccumulation process occurring for most metals in many exposed organisms under prolonged exposure [56]. 
Table 2. In vitro inhibition of CA activity by trace metals. $\mathrm{IC}_{50}$ and $K_{\mathrm{i}}$ values are expressed as $\mathrm{mM}$ concentrations.

\begin{tabular}{|c|c|c|c|c|c|c|c|c|c|}
\hline Species & Tissue & $\mathrm{Cd}^{2+}(\mathrm{mM})$ & $\mathrm{Cu}^{2+}$ & $\mathrm{Hg}^{2+}$ & $\mathrm{Zn}^{2+}$ & $\mathrm{Co}^{2+}$ & $\mathrm{Pb}^{2+}$ & $\mathrm{Ag}^{+}$ & Ref. \\
\hline $\begin{array}{l}\text { Callinectes } \\
\text { sapidus }\end{array}$ & gills & Ki $0.1 \times 10^{-3}$ & Ki $3.6 \times 10^{-3}$ & & Ki $2-6 \times 10^{-3}$ & & & Ki $0.05 \times 10^{-3}$ & [51] \\
\hline Carcinus maenas & gills & Ki $0.6-2.5$ & Ki $0.6-2.5$ & & Ki 0.6-2.5 & & & & [51] \\
\hline Anguilla anguilla & gills & $\mathrm{IC}_{50} 9.9 \times 10^{-3}$ & & & & & & & [46] \\
\hline Anguilla anguilla & intestine & $\mathrm{IC}_{50} 36.4 \times 10^{-3}$ & & & & & & & [46] \\
\hline Sparus aurata & liver & $\begin{array}{c}\text { Ki } 17.7 \\
\text { (non-competitive) }\end{array}$ & $\begin{array}{c}\text { Ki } 36.2 \\
\text { (non-competitive) }\end{array}$ & & & & & $\begin{array}{c}\text { Ki } 0.02 \\
\text { (non-competitive) }\end{array}$ & [48] \\
\hline $\begin{array}{l}\text { Ictalurus } \\
\text { punctatus }\end{array}$ & erythrocyte & $\mathrm{IC}_{50} 0.9$ & $\mathrm{IC}_{50} 0.065$ & & $\mathrm{IC}_{50} 0.7$ & & & $\mathrm{IC}_{50} 0.035$ & [44] \\
\hline $\begin{array}{c}\text { Oncorhynchus } \\
\text { mykiss }\end{array}$ & brain & Ki $94.2 \times 10^{-3}$ & $\begin{array}{l}\text { Ki } 27.6 \times 10^{-3} \\
\text { (non-competitive) }\end{array}$ & & Ki 1.20 & Ki 0.035 & & & [49] \\
\hline $\begin{array}{c}\text { Acipenser } \\
\text { gueldenstaedti }\end{array}$ & erythrocyte & & $\mathrm{IC}_{50} 5.2$ & & $\mathrm{IC}_{50} 2.8$ & & & $\mathrm{IC}_{50} 1.7$ & [53] \\
\hline $\begin{array}{l}\text { Dicentrarchus } \\
\text { labrax }\end{array}$ & liver & & & Ki 0.76 & $\begin{array}{c}\text { Ki } 0.72 \\
\text { (competitive) }\end{array}$ & $\begin{array}{c}\text { Ki } 0.53 \\
\text { (competitive) }\end{array}$ & $\begin{array}{c}\text { Ki } 0.24 \\
\text { (competitive) }\end{array}$ & & [47] \\
\hline Gallus & erythrocyte & & $\begin{array}{c}\text { Ki } 2.78 \\
\text { (competitive) }\end{array}$ & $\begin{array}{c}\text { Ki } 1.26 \\
\text { (competitive) }\end{array}$ & & & $\begin{array}{c}\text { Ki } 0.97 \\
\text { (competitive) }\end{array}$ & & [55] \\
\hline Ovis aries & kidney & Ki 1.04 (competitive) & $\begin{array}{c}\text { Ki } 4.70 \\
\text { (competitive) }\end{array}$ & & $\begin{array}{c}\text { Ki } 0.96 \\
\text { (competitive) }\end{array}$ & & & & [54] \\
\hline Homo sapiens & $\begin{array}{l}\text { Erythrocyte, } \\
\text { CA I }\end{array}$ & & Ki 3.22 & $\begin{array}{c}\text { Ki } 3.22 \\
\text { (uncompetitive) }\end{array}$ & & $\begin{array}{c}\text { Ki } 1.45 \\
\text { (competitive) }\end{array}$ & $\begin{array}{c}\mathrm{Ki} 1 \\
\text { (non-competitive) }\end{array}$ & & [52] \\
\hline Homo sapiens & $\begin{array}{l}\text { Erythrocyte, } \\
\text { CA II }\end{array}$ & & Ki 0.312 & $\begin{array}{c}\text { Ki } 0.312 \\
\text { (uncompetitive) }\end{array}$ & & $\begin{array}{c}\text { Ki } 1.7 \\
\text { (non-competitive) }\end{array}$ & $\begin{array}{c}\text { Ki } 0.056 \\
\text { (competitive) }\end{array}$ & & [52] \\
\hline
\end{tabular}


The inhibitory effect of metals on CA activity demonstrated in in vitro studies has been confirmed by works carried out in in vivo exposure conditions. In the mantle of the filter-feeding mussel Mytilus galloprovincialis, CA was significantly inhibited by exposure to $1.78 \mu \mathrm{M} \mathrm{Cd}^{2+}$ for 15 days [57]. Considering the role of $\mathrm{CA}$ in carbonate salt deposition, the inhibitory effect of $\mathrm{Cd}^{2+}$ on mantle $\mathrm{CA}$ activity could explain the significant decrease in shell growth previously observed in $M$. galloprovincialis exposed to heavy metals. [58]. In the marine anemone Aiptasia pallida, a decrease of CA activity was observed after waterborne exposure to metal mixtures $\left(\mathrm{Cu}^{2+}, \mathrm{Zn}^{2+}, \mathrm{Ni}^{2+}\right.$ and $\left.\mathrm{Cd}^{2+}\right)$ with a significant CA activity reduction following treatment with $100 \mu \mathrm{g} / \mathrm{L}$ for three days [59]. CA activity in the gills of the freshwater bivalve Anodonta anatine was significantly inhibited by the exposure to $0.35 \mu \mathrm{M} \mathrm{Cu}^{2+}$ for 15 days [60]. A CA activity decrease with increasing exposure concentrations of $\mathrm{Cu}^{2+}$ was observed in two species of scleractinian corals, such as Acropora cervicornis and Montastraea faveolata. Significant effects were detected in A. cervicornis exposed to 10 and $20 \mu \mathrm{g} / \mathrm{L} \mathrm{Cu}^{2+}$ and in M. faveolata exposed to $20 \mu \mathrm{g} / \mathrm{L} \mathrm{Cu}^{2+}$ for five weeks [61], respectively. A significant decrease in CA activity was recorded also in the anemones Condylactis gigantea and Stichodactyla helianthus exposed to $\mathrm{Cu}^{2+}, \mathrm{Ni}^{2+}, \mathrm{Pb}^{2+}$ and $\mathrm{V}^{2+}$ for $48 \mathrm{~h}$ [62].

From all of the available studies, a great variability in the sensitivity of CA activity to in vitro and in vivo metal exposure was observed among species, tissues and metals. This great variability can be explained by the complexity and multifaceted aspects of the binding of metals with CA isoforms, producing a number of different inhibitory responses to different metals in different tissues and species. It is possible to hypothesize that structural differences in CA isoforms could generate different metal-binding affinities and in turn different inhibitory responses.

\section{Metals and CA Protein Expression}

The inhibition exerted by some metals on CA-specific isoforms, as a result of the displacement of the native metal cofactor or the binding to other sites in the CA molecule, did not explain all of the biological effects of metals on CA.

It is known in plants and phytoplankton that biosynthesis of CA may be regulated by some environmental factors, including environmental trace metal concentrations [26,63]. Concerning animals, less information is available on this aspect. Some works indicate CA protein expression to be influenced by $\mathrm{Zn}^{2+}$ availability. For example, in humans, patients with CAVI deficiency show stimulation of CAVI synthesis/secretion by $\mathrm{Zn}^{2+}$ treatment [64], presumably through metal-induced upregulation of the CAIV gene. In rats, zinc deficiency induced a decrease in CAII protein expression in the submandibular gland [65].

In the fish Cyprinodon variegatus, CAII gene expression in gills and intestine was influenced by $\mathrm{Cu}^{2+}$ exposure in a concentration-dependent manner, with a two-fold upregulation in the gills and a three-fold upregulation in the intestine following nine days of exposure to $100 \mathrm{mg} / \mathrm{L} \mathrm{Cu}^{2+}$ [66]. The effect of $\mathrm{Cu}^{2+}$ on CA expression appears more complex if we consider that the metal in the same fish is also able to interfere with the regulation of CA expression by osmotic stress, disrupting the osmotic stress induction of the intestinal CAII. These results outline that CA plays a role in the combined effects of copper and osmotic stress on ion homeostasis and show how this enzyme represents a factor linking the physiological responses of the organism to multiple stresses.

In mussels, Caricato et al. [67] demonstrated that cadmium exposure $\left(1.785 \mu \mathrm{M} \mathrm{CdCl}_{2}\right.$ for 14 days) enhances CA protein expression in digestive gland, as assessed by Western blotting analysis, CA activity measurement and immunofluorescence analysis in both laboratory and field experiments $[67,68]$. In basal conditions, digestive gland cells show a high CA specific activity, which can be functional to the well-developed lysosomal compartment of these cells. In fact CA, catalyzing the $\mathrm{H}^{+}$production from metabolic $\mathrm{CO}_{2}$, can provide the $\mathrm{H}^{+}$necessary for the lysosome acidification. Therefore, the authors hypothesized that the observed metal-induced CA increased expression in mussel digestive gland is functionally related to the activation of the lysosomal system known to occur in pollutant-exposed organisms [69] and well described in mussel digestive gland [70]. 
The metal induction of CA expression arouses the question of how to interpret the different opposite effects that some metals can exert on CA, such as inhibition of the activity and upregulation of the gene expression. In mussel digestive gland, the $\mathrm{IC}_{50}$ value for $\mathrm{Cd}^{2+}$ inhibition of $\mathrm{CA}$ activity in vitro was in the millimolar range, while $\mathrm{CA}$ induction was observed following in vivo exposure to $1.785 \mu \mathrm{M} \mathrm{CdCl}_{2}$ for two weeks [67]. In this case, it is possible to argue that the effect of $\mathrm{Cd}^{2+}$ on CA is dose-dependent with upregulation of $\mathrm{CA}$ expression at low concentrations and inhibition of the $\mathrm{CA}$ activity at higher concentrations. Moreover, the type of effect of metals on CA, induction vs. inhibition, is tissue specific. In fact, in the case of mussels, the same organisms exposed to $1.785 \mu \mathrm{M} \mathrm{CdCl}_{2}$ for two weeks showed mantle CA significantly inhibited [57], while digestive gland CA significantly increased [67].

Although future work is needed to clarify this intriguing aspect and to deepen the research on the regulation of CA expression by metals, these results enrich the panorama of information about the effects of metals on CA, pointing to the importance of the concentration of exposure, the type of exposure and the metal and tissue specificity on the observed effects.

\section{CA and Trace Metals: Applicative Insights and Perspectives}

As emerged from the above described studies, the relationships between metals and CA are complex and multifaceted, metals being cofactors of CA, but also inhibitors of CA activity and modulators of CA expression. In this field, new applicative perspectives have been recently developed in the biotechnological and environmental fields, allowing translating new advances in basic science on the interaction between CA and metals into practice and novel applications.

\subsection{CA Metallovariants}

The ability of many divalent metal ions, such as $\mathrm{Co}^{2+}, \mathrm{Ni}^{2+}, \mathrm{Mn}^{2+}, \mathrm{Cu}^{2+}, \mathrm{Cd}^{2+}$ and $\mathrm{Hg}^{2+}$, to easily bind to the three-histidine moiety within the $\mathrm{CA}$ active site in transmetallation experiments generated a number of CA metallovariants.

The interest in CA metallovariants goes beyond the study of the metal-protein interaction in the catalytic site structure. It allows probing the changes certain metals make to the function of the enzyme, including new catalytic reactions. This has been observed particularly in CA enzymes containing $\mathrm{Co}^{2+}$ and $\mathrm{Mn}^{2+}$ metal centers [71]. The natural function of CA is to catalyze the reversible hydration of $\mathrm{CO}_{2}$ to $\mathrm{HCO}_{3}{ }^{-}$, but it is also known for its ability to catalyze the hydrolysis of esters with moderate enantioselectivity. Replacing zinc with manganese in the active site produced the manganese-substituted carbonic anhydrase (CA[Mn]) with peroxidase activity [72]. In the presence of bicarbonate and hydrogen peroxide, $\mathrm{CA}[\mathrm{Mn}]$ catalyzed the efficient oxidation of $O$-dianisidine with $K_{\text {cat }} / K_{\mathrm{m}}$ comparable to that for horseradish peroxidase. CA[Mn] also catalyzed the moderately enantioselective epoxidation of olefins to epoxides. This enantioselectivity of CA[Mn] is similar to that observed in natural heme-based peroxidases, with the advantage that CA[Mn] avoids the formation of aldehyde side products [71].

Therefore, the ability of some transition metals to displace the native $\mathrm{Zn}^{2+}$ in the catalytic site discloses a CA catalytic promiscuity that has begun to be recognized as a valuable research and synthesis tool in potential biotechnological applications, leading to improvements in existing catalysts and providing novel synthesis pathways currently not available.

\subsection{CA-Based Biosensors for Metal Ions}

Pollution by trace metals is a world-wide problem, which raises concerns about potential effects on human health and the environment [73]. Mining and smelting, industrial and urban waste, wastewater discharges and shipping activity are the major anthropogenic sources of metals in the aquatic environment. Many sensitive and selective analytical methods for the detection of metal ions at low concentrations in environmental samples have been developed. In this field, great is the interest for simple, rapid and inexpensive alternatives to the classical analytical methods, able to provide a 
continuous analysis of metal concentration in situ and in real time. This interest is expressed by the development of biosensors for trace metal detection. Some of them are fluorescence-based biosensors for the determination of free metals in solution [74-76], such as $\mathrm{Cu}^{2+}, \mathrm{Co}^{2+}, \mathrm{Zn}^{2+}, \mathrm{Cd}^{2+}$ and $\mathrm{Ni}^{2+}$ at concentrations down the picomolar range [76,77]. They utilize the affinity of the apoCA (in general variants of human CAII) for metals [76,78].

Therefore, the high affinity of CA for metals has driven the development of CA-based biosensing that has been shown to be a viable approach for determining certain divalent cations in environmental media, serving also as an archetype for other fluorescence-based biosensors [79].

\subsection{CA-Based Ecotoxicological Biomarkers and Bioassays for Metal Pollution Assessment}

In the last few decades, the use of effect-based methodologies, such as ecotoxicological bioassays and biomarkers, has received growing interest in environmental monitoring and assessment. Ecotoxicity bioassays are widely used for the assessment of environmental media quality, because they provide an integrated measurement of the various complex effects exerted by contaminants present in an environmental sample on the test biological system [80,81]. On the other hand, molecular and cellular biomarkers measured in exposed organism in the field can be helpful for detecting the occurrence of pollutant-induced stress syndrome in living organisms and gaining insight regarding the mechanisms causing the observed effects of chemicals $[82,83]$. Bioassays and biomarkers provide useful information about the degree of exposure to pollutants and the resulting effects on the organisms. In this regard, the use of bioassay/biomarkers provides early warning information useful for improving the processes of environmental risk assessment [84].

Recently, new perspectives on the potential use of CA as pollution biomarkers in environmental biomonitoring rose from the sensitivity of CA activity and expression to trace metals in several species.

Therefore, CA measurements have been included in multi-biomarker approaches on bioindicator organisms in field studies [85]. For example CA activity inhibition measurement in the bioindicator fish Pimelodus maculatus has been included in the multi-marker biomonitoring of three water reservoirs along the Paraiba do Sul River in an industrialized area of Brazil [86]. In corals, CA activity inhibition by metal exposure has been related to inhibition of coral growth through alteration of the calcification process, and it has been suggested as a potential biomarker of exposure to metal pollution [61].

The applicability of digestive gland CA activity and expression in a multimarker approach has been also demonstrated in the bioindicator organism Mytilus galloprovincialis $[67,87]$ in two studies addressing the ecotoxicological biomonitoring and assessment of a coastal marine area in Southern Italy.

Branchial CA activity measured in the filter-feeding species Crassostrea rhizophorae was shown to be very responsive to coastal contamination in a recent study carried out in three human-impacted Brazilian estuaries [88]. Data were consistent with the usefulness of branchial CA in this species as a supporting biomarker for inexpensive and rapid analysis.

All of the available studies demonstrate the applicability of metal-induced CA alterations as pollution biomarkers. However, the successful use of CA as a biomarker in environmental biomonitoring requires a thorough knowledge of the specific metal-induced CA response in the specific bioindicator species used, because of the high species-specific and tissue-specific effects of metals on CA isoforms.

The in vitro inhibition of CA activity by metals has been applied by Lionetto et al. $[57,89,90]$ to the development of an in vitro bioassay sensitive to the synergic effects of metals in a mixture and useful for the toxicity assessment of environmental aqueous samples [90]. This patented method has been recently applied to the monitoring of harbor sediments [68] and of reclaimed waste waters [91], showing a high agreement with standardized in vivo bioassays.

All of the studies carried out to date on the in vitro and in vivo sensitivity of CA to trace metals contribute to developing effect-based methodologies, such as CA-based pollution biomarkers and 
bioassays. They allow translating new advances in basic science into practice and novel applications in environmental biomonitoring (Figure 3).

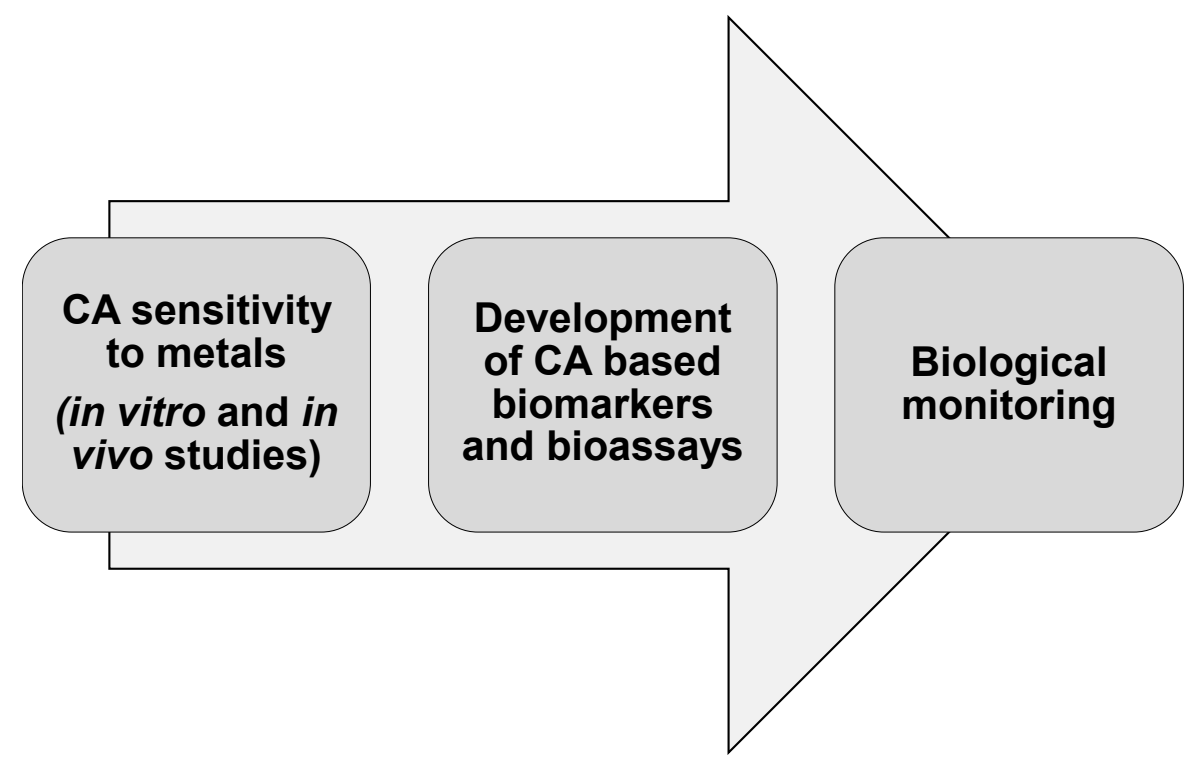

Figure 3. From in vivo and in vivo assessment of the sensitivity of CA to trace metals to environmental monitoring.

\section{Conclusions}

Although CA has been widely investigated in several aspects of its structure and functions, its complex relationships with metals have been only partially investigated to date, and some questions still remain to be clarified, such as, for example, the metal regulation of CA expression and its underlying mechanisms. This is an intriguing aspect of the research on this metalloenzyme that could raise new perspectives in the understanding of CA function and regulation.

The responses of CA activity and expression to metal exposure in animals need to be further characterized, and this could improve the potentiality of this enzyme for biotechnological and environmental applications.

Acknowledgments: This study was supported by PRIN (Progetti di Rilevate Interesse Nazionale) project 2010-2011 prot. 2010ARBLT7_005.

Author Contributions: All authors contributed equally and extensively to this work. All authors in collaboration designed the study, analysed and discussed the literature, and wrote the manuscript.

Conflicts of Interest: The authors declare no conflict of interest.

\section{References}

1. Supuran, C.T. Carbonic anhydrase inhibitors. Bioorg. Med. Chem. Lett. 2010, 20, 3467-3474. [CrossRef] [PubMed]

2. Del Prete, S.; Vullo, D.; Fisher, G.M.; Andrews, K.T.; Poulsen, S.A.; Capasso, C.; Supuran, C.T. Discovery of a new family of carbonic anhydrases in the malaria pathogen Plasmodium falciparum-The $\eta$-carbonic anhydrases. Bioorg. Med. Chem. Lett. 2014, 24, 4389-4396. [CrossRef] [PubMed]

3. Ivanov, B.N.; Ignatova, L.K.; Romanova, A.K. Diversity in forms and functions of carbonic anhydrase in terrestrial higher plants. Russ. J. Plant Physiol. 2007, 54, 143-162. [CrossRef]

4. Cannon, G.C.; Heinhorst, S.; Kerfeld, C.A. Carboxysomal carbonic anhydrases: Structure and role in microbial $\mathrm{CO}_{2}$ fixation. BBA Proteins Proteom. 2010, 1804, 382-392. [CrossRef] [PubMed]

5. Neri, D.; Supuran, C.T. Interfering with $\mathrm{pH}$ regulation in tumors as a therapeutic strategy. Nat. Rev. Drug Discov. 2011, 10, 767-777. [CrossRef] [PubMed] 
6. Supuran, C.T. Carbonic anhydrases: Novel therapeutic applications for inhibitors and activators. Nat. Rev. Drug Discov. 2008, 7, 168-181. [CrossRef] [PubMed]

7. Kimber, M.S.; Pai, E.F. The active site architecture of Pisum sativum $\beta$-carbonic anhydrase is a mirror image of that of $\alpha$-carbonic anhydrases. EMBO J. 2000, 19, 1407-1418. [CrossRef] [PubMed]

8. Smith, K.S.; Ferry, J.G. Prokaryotic carbonic anhydrases. FEMS Microbiol. Rev. 2000, 24, 335-366. [CrossRef] [PubMed]

9. Alber, B.E.; Ferry, J.G. A carbonic anhydrase from the archeon Methanosarcina thermophile. Proc. Natl. Acad. Sci. USA 1994, 91, 6909-6913. [CrossRef] [PubMed]

10. Roberts, S.B.; Lane, T.W.; Morel, F.M.M. Carbonic anhydrase in the marine diatom Thalassiosira weissflogii (Bacillariophyceae). J. Phycol. 1997, 33, 845-850. [CrossRef]

11. Tripp, B.C.; Smith, K.S.; Ferry, J.G. Carbonic anhydrase: New insights for an ancient enzyme. J. Biol. Chem. 2001, 276, 48615-48618. [CrossRef] [PubMed]

12. Xu, Y.; Supuran, C.T.; Morel, F.M.M. Cadmium-Carbonic Anhydrase. In Encyclopedia of Inorganic and Bioinorganic Chemistry; John Wiley \& Sons: New York, NY, USA, 2011.

13. Supuran, C.T.; Scozzafava, A.; Casini, A. Carbonic anhydrase inhibitors. Med. Res. Rev. 2003, 23, $146-189$. [CrossRef] [PubMed]

14. Supuran, C.T.; Scozzafava, A. Carbonic anhydrases as targets for medicinal chemistry. Bioorg. Med. Chem. Lett. 2007, 15, 4336-4350. [CrossRef] [PubMed]

15. Innocenti, A.; Scozzafava, S.; Parkkila, L.; Puccetti, G.; de Simone, G.; Supuran, C.T. Investigations of the esterase, phosphatase, and sulfatase activities of the cytosolic mammalian carbonic anhydrase isoforms I, II, and XIII with 4-nitrophenyl esters as substrates. Bioorg. Med. Chem. Lett. 2008, 18, 2267-2271. [CrossRef] [PubMed]

16. De Simone, G.; di Fiore, A.; Capasso, C.; Supuran, C.T. The zinc coordination pattern in the eta-carbonic anhydrase from Plasmodium falciparum is different from all other carbonic anhydrase genetic families. Bioorg. Med. Chem. Lett. 2015, 25, 1385-1389. [CrossRef] [PubMed]

17. Berg, J.M.; Tymoczko, J.L.; Stryer, L. Biochemistry, 7th ed.; W.H. Freeman: New York, NY, USA, 2012.

18. Williams, R.J.P. The biochemistry of zinc. Polyhedron 1987, 6, 61-69. [CrossRef]

19. Maret, W. Zinc biochemistry: From a single zinc enzyme to a key element of life. Adv. Nutr. 2013, 4, 82-91. [CrossRef] [PubMed]

20. Vahrenkamp, H. Why does nature use zinc-A personal view. Dalton Trans. 2007, 42, 4751-4759. [CrossRef] [PubMed]

21. Supuran, C.T. Structure-based drug discovery of carbonic anhydrase inhibitors. J. Enzym. Inhib. Med. Chem. 2012, 27, 759-772. [CrossRef] [PubMed]

22. MacAuley, S.R.; Zimmerman, S.A.; Apolinario, E.E.; Evilia, C.; Hou, Y.; Ferry, J.G.; Sowers, K.R. The archetype $\gamma$-class carbonic anhydrase (Cam) contains iron when synthesized in vivo. Biochemistry 2009. [CrossRef] [PubMed]

23. Tripp, B.C.; Bell, C.B.; Cruz, F.; Krebs, C.; Ferry, J.G. A role for iron in an ancient carbonic anhydrase. J. Biol. Chem. 2004, 279, 21677-21677. [CrossRef] [PubMed]

24. Ferry, J.G. The gamma class of carbonic anhydrases. Biochim. Biophys. Acta 2010, 1804, 374-381. [CrossRef] [PubMed]

25. Wu, Y.; Zhao, X.; Li, P.; Huang, H. Impact of Zn, Cu, and Fe on the Activity of Carbonic Anhydrase of Erythrocytes in Ducks. Biol. Trace Elem. Res. 2007, 118, 227-232. [CrossRef] [PubMed]

26. Lane, T.W.; Morel, F.M.M. A biological function for cadmium in marine diatoms. Proc. Natl. Acad. Sci. USA 2000, 97, 4627-4631. [CrossRef] [PubMed]

27. Lane, T.W.; Saito, M.A.; George, G.N.; Pickering, I.J.; Prince, R.C.; Morel, F.M.M. Biochemistry: A cadmium enzyme from a marine diatom. Nature 2005, 435. [CrossRef] [PubMed]

28. Park, H.; McGinn, P.J.; Morel, F.M.M. Expression of cadmium carbonic anhydrase of diatoms in seawater. Aquat. Microbial. Ecol. 2008, 51, 183-193. [CrossRef]

29. Lionetto, M.G.; Lionetto, M.G.; Vilella, S.; Trischitta, F.; Cappello, M.S.; Giordano, M.E.; Schettino, T. Effects of $\mathrm{CdCl}_{2}$ on electrophysiological parameters in the intestine of the teleost fish, Anguilla anguilla. Aquat. Toxicol. 1998, 41, 251-264.

30. Yee, D.; Morel, F.M.M. In vivo substitution of zinc by cobalt in carbonic anhydrase of a marine diatom. Limnol. Oceanogr. 1996, 41, 573-577. [CrossRef] 
31. Mahon, B.P.; Pinar, M.A.; McKenna, R. Targeting Carbonic Anhydrase IX Activity and Expression. Molecules 2015, 20, 2323-2348. [CrossRef] [PubMed]

32. Dutta, S.; Goodsell, D. Carbonic anhydrase. Available online: http://pdb101.rcsb.org/motm/49 (accessed on 12 January 2016).

33. Håkansson, K.; Wehnert, A.; Liljas, A. X-ray analysis of metal-substituted human carbonic anhydrase II derivatives. Acta Crystallogr. D 1994, 50, 93-100. [CrossRef] [PubMed]

34. Kogut, K.A.; Rowlett, R.S. A comparison of the mechanisms of $\mathrm{CO}_{2}$ hydration by native and $\mathrm{Co}^{2+}$-substituted carbonic anhydrase II. J. Biol. Chem. 1987, 262, 16417-16424. [PubMed]

35. Marino, T.; Russo, N.; Toscano, M. A Comparative Study of the Catalytic Mechanisms of the Zinc and Cadmium Containing Carbonic Anhydrase. J. Am. Chem. Soc. 2005, 127, 4242-4253. [CrossRef] [PubMed]

36. Led, J.J.; Neesgaard, E. Paramagnetic Carbon-13 NMR Studies of the Kinetics and Mechanism of the $\mathrm{HCO}_{3} / \mathrm{CO}_{2}$ Exchange Catalyzed by Manganese(II) Human Carbonic Anhydrase I. Biochemistry 1987, 26, 183-192. [CrossRef] [PubMed]

37. Sven, L. Structure and mechanism of carbonic anhydrase. Pharmacol. Ther. 1997, 74, 1-20.

38. Hoffmann, K.M.; Samardzic, D.; van den Heever, K.; Rowlett, R.S. Co(II)-substituted Haemophilus influenzae b-carbonic anhydrase: Spectral evidence for allosteric regulation by $\mathrm{pH}$ and bicarbonate ion. Arch. Biochem. Biophys. 2011, 511, 80-87. [CrossRef] [PubMed]

39. Eriksson, E.A.; Kylsten, P.M.; Jones, A.T.; Liljas, A. Crystallographic studies of inhibitor binding sites in human carbonic anhydrase II; A penta coordinated binding of the SCN- ion to the zinc at high pH. Proteins 1988, 4, 283-293. [CrossRef] [PubMed]

40. Hogeback, J.; Schwarzer, M.; Wehe, C.A.; Sperlingab, M.; Karst, U. Investigating the adduct formation of organic mercury species with carbonic anhydrase and hemoglobin from human red blood cell hemolysate by means of LC/ESI-TOF-MS and LC/ICP-MS. Metallomics 2015. [CrossRef] [PubMed]

41. Tu, C.; Wynns, G.C.; Silverman, D.N. Inhibition by cupric ions of ${ }^{18} \mathrm{O}$ exchange catalyzed by human carbonic anhydrase II. Relation to the interaction between carbonic anhydrase and hemoglobin. J. Biol. Chem. 1981, 256, 9466-9470. [PubMed]

42. Song, H.; Weitz, A.C.; Hendrich, M.P.; Lewis, E.A.; Emerson, J.P. Building reactive copper centers in human carbonic anhydrase II. J. Biol. Inorg. Chem. 2013, 18, 595-598. [CrossRef] [PubMed]

43. Nettles, W.L.; Song, H.; Farquhar, E.R.; Fitzkee, N.C.; Emerson, J.P. Characterization of the copper(II) binding sites in human carbonic anhydrase II. Inorg. Chem. 2015, 54, 5671-5680. [CrossRef] [PubMed]

44. Christensen, G.M.; Tucker, J.H. Effects of selected water toxicants on the in vitro activity of fish carbonic anhydrase. Chem. Biol. Interact. 1976, 13, 181-192. [CrossRef]

45. Lionetto, M.G.; Maffia, M.; Cappello, M.S.; Giordano, M.E.; Storelli, C.; Schettino, T. Effect of cadmium on carbonic anhydrase and $\mathrm{Na}^{+}-\mathrm{K}^{+}$-ATPase in eel, Anguilla anguilla, intestine and gills. Comp. Biochem. Physiol. A 1998, 120, 89-91. [CrossRef]

46. Lionetto, M.G.; Giordano, M.E.; Vilella, S.; Schettino, T. Inhibition of eel enzymatic activities by cadmium. Aquat. Toxicol. 2000, 48, 561-571. [CrossRef]

47. Ceyhun, S.B.; Şentürk, M.; Yerlikaya, E.; Erdoğan, O.; Küfrevioğlu, Ö.I.; Ekinci, D. Purification and characterization of carbonic anhydrase from the teleost fish Dicentrarchus labrax (European Seabass) liver and toxicological effects of metals on enzyme activity. Environ. Toxicol. Pharmacol. 2011, 32, 69-74. [CrossRef] [PubMed]

48. Kaya, E.D.; Söyüt, H.; Beydemir, S. Carbonic anhydrase activity from the gilthead sea bream (Sparus aurata) liver: The toxicological effects of heavy metals. Environ. Toxicol. Pharmacol. 2013, 36, 514-521. [CrossRef] [PubMed]

49. Soyut, H.; Beydemir, Ş.; Hisar, O. Effects of some metals on carbonic anhydrase from brains of rainbow trout. Biol. Trace Elem. Res. 2008, 123, 179-190. [CrossRef] [PubMed]

50. Vitale, A.M.; Monserrat, J.M.; Casthilo, P.; Rodriguez, E.M. Inhibitory effects of cadmium on carbonic anhydrase activity and ionic regulation of the estuarine crab, Chasmagnathus granulata (Decapoda, Grapsidae). Comp. Biochem. Physiol. C 1999, 122, 121-129. [CrossRef]

51. Skaggs, H.S.; Henry, R.P. Inhibition of carbonic anhydrase in the gills of two euryhaline crabs, Callinectes sapidus and Carcinus maenas, by heavy metals. Comp. Biochem. Physiol. C 2002, 133, 605-612. [CrossRef]

52. Ekinci, D.; Beydemir, Ş.; Küfrevioğlu, Ö.İ. In vitro inhibitory effects of some heavy metals on human erythrocyte carbonic anhydrases. J. Enzym. Inhib. Med. Chem. 2007, 22, 745-750. [CrossRef] [PubMed] 
53. Kolayli, S.; Karahalil, F.; Sahin, H.; Dicer, B.; Supuran, C.T. Characterization and inhibition studies of an $\alpha$-carbonic anhydrase from the endangered sturgeon species Acipenser gueldenstaedti. J. Enzym. Inhib. Med. Chem. 2011, 26, 895-900. [CrossRef] [PubMed]

54. Demirdağ, R.; Comakli, V.; Kuzu, M.; Yerlikaya, E.; Şentürk, M. Purification and characterization of carbonic anhydrase from Ağrı Balık Lake Trout Gill (Salmo trutta labrax) and effects of sulfonamides on enzyme activity. J. Biochem. Mol. Toxicol. 2013, 29, 278-282. [CrossRef] [PubMed]

55. Mercan, L.; Ekinci, D.; Supuran, C.T. Characterization of carbonic anhydrase from Turkish native "Gerze" chicken and influences of metal ions on enzyme activity. J. Enzym. Inhib. Med. Chem. 2014, 29, 773-776. [CrossRef] [PubMed]

56. Jebali, J.; Chouba, L.; Bannia, M.; Boussetta, H. Comparative study of the bioaccumulation and elimination of trace metals $(\mathrm{Cd}, \mathrm{Pb}, \mathrm{Zn}, \mathrm{Mn}$ and $\mathrm{Fe})$ in the digestive gland, gills and muscle of bivalve Pinna nobilis during a field transplant experiment. J. Trace Elem. Med. Biol. 2014, 28, 212-217. [CrossRef] [PubMed]

57. Lionetto, M.G.; Caricato, R.; Erroi, E.; Giordano, M.E.; Schettino, T. Potential application of carbonic anhydrase activity in bioassay and biomarker studies. Chem. Ecol. 2006, 22, S119-S125. [CrossRef]

58. Soto, M.; Ireland, M.P.; Marigómez, I. Changes in mussel biometry on exposure to metals: Implications in estimation of metal bioavailability in "Mussel-Watch" programmes. Sci. Total Environ. 2000, 247, 175-187. [CrossRef]

59. Brock, J.R.; Bielmyer, G.K. Metal accumulation and sublethal effects in the sea anemone, Aiptasia pallida, after waterborne exposure to metal mixtures. Comp. Biochem. Physiol. C 2013, 158, 150-158. [CrossRef] [PubMed]

60. Santini, O.; Chahbane, N.; Vasseur, P.; Frank, H. Effects of low-level copper exposure on Ca ${ }^{2+}$-ATPase and carbonic anhydrase in the freshwater bivalve Anodonta anatine. Toxicol. Environ. Chem. 2011, 93, 1826-1837. [CrossRef]

61. Bielmyer, G.K.; Grosell, M.; Bhagooli, R.; Baker, A.C.; Langdon, C.; Gillette, P.; Capo, T.R. Differential effects of copper on three species of scleractinian corals and their algal symbionts (Symbiodinium spp.). Aquat. Toxicol. 2010, 97, 125-133. [CrossRef] [PubMed]

62. Gilbert, A.L.; Guzman, H.M. Bioindication potential of carbonic anhydrase activity in anemones and corals. Mar. Pollut. Bull. 2001, 42, 742-744. [CrossRef]

63. Khan, N.A.; Singh, S.; Anjum, N.A.; Nazar, R. Cadmium effects on carbonic anhydrase, photosynthesis, dry mass and antioxidative enzymes in wheat (Triticum aestivum) under lowand sufficient zinc. J. Plant Interact. 2008, 3, 31-37. [CrossRef]

64. Henkin, R.; Martin, B.M.; Agarwal, R. Efficacy of exogenous oral zinc in treatment of patients with carbonic anhydrase VI deficiency. Am. J. Med. Sci. 1999, 318, 392-405. [CrossRef]

65. Goto, T.; Shirakawa, H.; Furukawa, Y.; Komai, M. Decreased expression of carbonic anhydrase isozyme II, rather than of isozyme VI, in submandibular glands in long term zinc-deficient rats. Br. J. Nutr. 2008, 99, 248-253. [CrossRef] [PubMed]

66. De Polo, A.; Margiotta-Casaluci, L.; Lockyer1, A.E.; Scrimshaw, M.D. A new role for carbonic anhydrase 2 in the response of fish to copper and osmotic stress: Implications for multi-stressor studies. PLoS ONE 2014, 9. [CrossRef]

67. Caricato, R.; Lionetto, M.G.; Dondero, F.; Viarengo, A.; Schettino, T. Carbonic anhydrase activity in Mytilus galloprovincialis digestive gland: Sensitivity to heavy metal exposure. Comp. Biochem. Physiol. C 2010, 152, 241-247.

68. Lionetto, M.G.; Caricato, R.; Giordano, M.E.; Erroi, E.; Schettino, T. Carbonic anydrase and chemical pollutants: New applied perspectives. In Proceedings of the 65th Annual Meeting of the Italian Physiological Society, Anacapri, Italy, 28-30 September 2014.

69. Köhler, A. Lysosomal perturbations in fish liver as indicators for toxic effects of environmental pollution. Comp. Biochem. Physiol. 1991, 100, 123-127. [CrossRef]

70. Moore, M.N.; Simpson, M.G. Molecular and cellular pathology in environmental impact assessment. Aquat. Toxicol. 1992, 22, 313-322. [CrossRef]

71. Jing, Q.; Okrasa, K.; Kazlauskas, R.J. Manganese-Substituted $\alpha$-Carbonic Anhydrase as an Enantioselective Peroxidase. Top. Organomet. Chem. 2009, 25, 45-61.

72. Okrasa, K.; Kazlauskas, R.J. Manganese-Substituted Carbonic Anhydrase as a New Peroxidase. Chem. Eur. J. 2006, 12, 1587-1596. [CrossRef] [PubMed] 
73. De Mora, S.; Fowler, S.W.; Wyse, E.; Azemard, S. Distribution of heavy metals in marine bivalves, fish and coastal sediments in the Gulf and Gulf of Oman. Mar. Pollut. Bull. 2004, 49, 410-424. [CrossRef] [PubMed]

74. Zeng, H.H.; Thompson, R.B.; Maliwal, B.P.; Fones, G.R.; Moffett, J.W.; Fierke, C.A. Real-time determination of picomolar free $\mathrm{Cu}$ (II) in seawater using a fluorescence-based fiber optic biosensor. Anal. Chem. 2003, 75, 6807-6812. [CrossRef] [PubMed]

75. Bozym, R.; Hurst, T.K.; Westerberg, N.; Stoddard, A.; Fierke, C.A.; Frederickson, C.J.; Thompson, R.B. Determination of zinc using carbonic anhydrase-based fluorescence biosensors. Methods Enzymol. 2008, 450, 287-309. [PubMed]

76. Fierke, C.A.; Thompson, R.B. Fluorescence-based biosensing of zinc using carbonic anhydrase. Biometals 2001, 14, 205-222. [CrossRef] [PubMed]

77. Mei, Y.J.; Frederickson, C.J.; Giblin, L.J.; Weiss, J.H.; Medvedeva, Y.; Bentley, P.A. Sensitive and selective detection of zinc ions in neuronal vesicles using PYDPY1, a simple turn-on dipyrrin. Chem. Commun. 2011, 47, 7107-7109. [CrossRef] [PubMed]

78. McCall, K.A.; Fierke, C.A. Probing determinants of the metal ion selectivity in carbonic anhydrase using mutagenesis. Biochemistry 2004, 43, 3979-3986. [CrossRef] [PubMed]

79. Thompson, R.B.; Bozym, R.A.; Cramer, M.L.; Stoddard, A.K.; Westerberg, N.M.; Fierke, C.A. Chapter 6: Carbonic anhydrase-based biosensing of metal ions: Issue and future prospects. In Fluorescence Sensors and Biosensors; Thompson, R.B., Ed.; CRC Press: Boca Raton, FL, USA, 2005.

80. Costa, C.R.; Olivi, P.; Botta, C.M.R.; Espindola, E.L.G. Toxicity in aquatic environments: Discussion and evaluation methods. Quim Nova 2008, 31, 1820-1830. [CrossRef]

81. Manzo, S.; de Nicola, F.; de Luca Picione, F.; Maisto, G.; Alfani, A. Assessment of the effects of soil PAH accumulation by a battery of ecotoxicological tests. Chemosphere 2008, 71, 1937-1944. [CrossRef] [PubMed]

82. Forbes, V.E.; Palmqvist, A.; Bach, L. The use and misuse of biomarkers in ecotoxicology. Environ. Toxicol. Chem. 2006, 25, 272-280. [CrossRef] [PubMed]

83. Schettino, T.; Caricato, R.; Calisi, A.; Giordano, M.E.; Lionetto, M.G. Biomarker approach in marine monitoring and assessment: New insights and perspectives. Open Environ. Sci. 2012, 6, 20-27. [CrossRef]

84. Martínez-Gómez, C.; Vethaak, A.D.; Hylland, K.; Burgeot, T.; Khöler, A.; Lyons, B.P.; Thain, J.; Gubbins, M.J.; Davies, I.M. A guide to toxicity assessment and monitoring effects at lower levels of biological organization following marine oil spills in European waters. J. Mar. Sci. 2010, 67, 1105-1118. [CrossRef]

85. Lionetto, M.G.; Caricato, R.; Giordano, M.E.; Erroi, E.; Schettino, T. Carbonic anhydrase as pollution biomarker: An ancient enzyme with a new use. Int. J. Environ. Res. Public Health 2012, 9, 3965-3977. [CrossRef] [PubMed]

86. De Andrade Brito, I.; Freire, C.A.; Yamamoto, F.Y.; de Assis, H.C.S.; Souza-Bastos, L.R.; Cestari, M.M.; de Castilhos Ghisi, N.; Prodocimo, V.; Filipak Neto, F.; de Oliveira Ribeiro, C.A. Monitoring water quality in reservoirs for human supply through multi-biomarker evaluation in tropical fish. J. Environ. Monit. 2012, 14, 615-625. [CrossRef] [PubMed]

87. Caricato, R.; Lionetto, M.G.; Schettino, T. Studio di biomarkers in mitili (Mytilus galloprovincialis) traslocati in Mar Piccolo e in Mar Grande di Taranto. Biol. Mar. Medit. 2009, 16, 136-147.

88. Azevedo-Linhares, M.; Freire, C.A. Evaluation of impacted Brazilian estuaries using the native oyster Crassostrea rhizophorae: Branchial carbonic anhydrase as a biomarker. Ecotoxicol. Environ. Saf. 2015, 122, 483-489. [CrossRef] [PubMed]

89. Lionetto, M.G.; Caricato, R.; Erroi, E.; Giordano, M.E.; Schettino, T. Carbonic anhydrase based environmental bioassay. Int. J. Environ. Anal. Chem. 2005, 85, 895-903. [CrossRef]

90. Schettino, T.; Lionetto, M.G.; Erroi, E. Method for enzymatic assessment of the toxicity of environmental aqueous matrices. Patent WO 2009/135537, 2 March 2012.

91. Lionetto, M.G.; Caricato, R.; Calisi, A.; Giordano, M.E.; Erroi, E.; Schettino, T. Biomonitoring of water and soil quality: A case study of ecotoxicological methodology application to the assessment of reclaimed agroindustrial wastewaters used for irrigation. Rend. Fis. Acc. Lincei 2015. [CrossRef]

(C) 2016 by the authors; licensee MDPI, Basel, Switzerland. This article is an open access article distributed under the terms and conditions of the Creative Commons by Attribution (CC-BY) license (http:/ / creativecommons.org/licenses/by/4.0/). 